\title{
Political Tourism/Tourist Revisited: Extending the Concept in a Developing Country's Point of View: A Thought-Provoking Case from Turkey
}

\author{
Nihat Kamil Anil, Gregor Pfajfar, and E. Tugba Kocabiyik
}

\begin{abstract}
The main goal of this chapter is to broaden the extent of political tourism phenomenon in order to explain recent practices in Turkish political life theoretically. Very few researchers dealt with the non-monetary outputs of tourism which falls beyond the conventional economical value of it. Thus firstly, the political tourism and political tourist concepts were reviewed by introducing daily election meetings as a new type of political tourism and election meeting tourists as a new political tourist classification. Secondly, the pull factors for election tourism were indicated as solidarity, support (emotional and/or financial), nostalgic/patriotic/nationalistic reasons following the motivation list of Simone-Charteris and Boyd (2010). The other motivators such as the thrill of political violence or none of the attractions defined by Simone-Charteris and Boyd (2010) were found relevant with the Turkish phenomena. Besides meeting areas can be introduced as attractions.
\end{abstract}

References available upon request.

\footnotetext{
N.K. Anil ( $\square)$

Kirklareli University, Kirklareli, Turkey

e-mail: nihatanil@yahoo.com

G. Pfajfar

University of Ljubljana, Ljubljana, Slovenia

e-mail: gregor.pfajfar@ef.uni-lj.si

E.T. Kocabiyik

Gediz University, Izmir, Turkey

e-mail: tugba.kocabiyik@gediz.edu.tr
}

L. Petruzzellis, R.S. Winer (eds.), Rediscovering the Essentiality of Marketing, 